\title{
Conflict's Emergence and Escalation in Participatory Protected Areas Management in Benin
}

\author{
Latifou Idrissou \\ Departement of Rural Economics and Sociology, Faculty of Agronomy, University of Parakou, Parakou, Benin \\ Email: latifou.idrissou@fa-up.bj
}

How to cite this paper: Idrissou, L. (2017) Conflict's Emergence and Escalation in Participatory Protected Areas Management in Benin. Journal of Geoscience and Environment Protection, 5, 60-78. https://doi.org/10.4236/gep.2017.59005

Received: July 20, 2017

Accepted: August 22, 2017

Published: August 25, 2017

Copyright $\odot 2017$ by author and Scientific Research Publishing Inc. This work is licensed under the Creative Commons Attribution International License (CC BY 4.0).

http://creativecommons.org/licenses/by/4.0/

\section{(c) (i) Open Access}

\begin{abstract}
This paper investigated factors that explain the emergence and escalation of conflict in participatory management of protected areas in Benin. It is based on evidences from three case-studies of conflict emergence and escalation in the implementation of participatory natural resources management in Benin supported with discussion from the literature. The study shows that conflicts in participatory management of protected areas emerge when parties involved co-construct opposing instead of same or at least overlapping frames in interaction. They often escalate when the negotiation fails to stimulate the parties to bring to the fore and address the opposing frames expressed only in "we-groups" of same stakeholders due to their strategic framing in interaction. We conclude that we cannot control the strategic framing of the parties in conflict but we should only be prepared to discover changes in discourse that contribute to the divergence in framing and thus influence them. For that, both formal and informal interactional contexts should be continuously checked during the negotiation process.
\end{abstract}

\section{Keywords}

Conflict Dynamics, Framing, Participatory Management, Protected Areas, Benin

\section{Introduction}

More than one century ago, three intellectual giants Darwin, Marx, and Freud, whose writings dominated the infancy of social psychology, have already emphasized the permanent presence of conflicts in societies [1]. Society is a dynamical system characterized with a set of interconnected elements (e.g. beliefs, feelings, behaviours) that change and evolve in time [2]. The incompatibility of 
these elements among individuals during their change and evolution often leads to conflict [3] [4] [5]. A society without conflicts is rather an odd one [6].

The scholars evoked above and others of their period viewed conflict from the perspective of "competitive struggle" and considered life as individuals' continuous fight against each others for survival [1]. Since then, the concept of conflict has evolved and conflict is no longer seen as only a destructive competition that should be avoided by any means. Nowadays, the aim is not to avoid conflict, but to make it possible for conflict to evolve without violence, death, suffering and misery [6]. Although conflicts have many negative impacts, many studies have recognized its value as a catalyst for positive social change [7]. Conflict can be extremely valuable in societies as the motor of progress or the mechanism by which injustice is removed [6]. In that sense, Desloges and Gauthier ([4], p. 111) pointed it out that:

As such, conflictual situations are neither positive nor negative but they can be used in a constructive or destructive way. Many authors consider that conflicts are crucial not only for social change but for the continuous creation of society by society itself. Therefore, conflict should not be viewed only as a dysfunctional relationship between individuals and communities that should be avoided at all cost but, also, as an opportunity for constructive change and growth.

The possibility for conflicts to yield positive or negative outcomes suggests that conflicts are still poorly understood and need to be investigated with the aim to manage them in an acceptable way [8].

Conflict over natural resources such as land, water, and forests is ubiquitous and will exist for the foreseeable future [7] [9] [10]. In natural resources management also, there is still a confusion whether or not conflicts are desirable [11]. In one hand, conflict over natural resources is regarded by some as negative phenomena because of their complexity and the unpredictability of their impact on these resources [8] [11]. Resource conflicts can sometimes become harsh and result in violence, resources degradation, the undermining of livelihoods, and uprooting of communities [9]. On the other hand, conflicts over natural resources have been viewed as important "tool" of environment management by ensuring the voices of the different stakeholders to be heard and new social demands to be responded to [11]. So, to some extent, conflicts over resources can be useful in defining the different needs for resources of the stakeholders and the society [9]. With this mix of the results of conflicts over resources, we still need to understand what make some conflicts cooperative and beneficial and others destructive competition in the management of natural resources.

This study investigated why and how conflict emerges and escalates in the implementation of participatory management of natural resources so that appropriate ways of handling them to yield constructive outcomes could be developed. We did so, by analyzing the role of discourse in three case studies of conflicts in the implementation of participation in the management of natural resources in 
Benin.

In a change process, discourse refers in terms of its content, to a set of change ideas and values, and in terms of usage, as a process of interaction focused on change formulation and communication [12]. Discourse helps to make sense of change, explain it, domesticate and at time celebrate it [13] [14]. However, change discourses are not always appropriated as individuals involved in the process do not simply adopt what is handled to them [15] [16]. Change discourses can be appropriated, edited and partially appropriated, or resisted by individuals involved in the change process [15] [17]. So, there are links between discourse and conflict as discourse is a major marker of difference between the people and nations [6]. In conflict situation, not only the enemies and the issue are represented in discourse but a discourse is constructed about them [6]. Thus, conflicts are rooted in discourse, which encompasses language, narrative, and communication [12] [18] [19] [20] [21] [22]. In this study, we then focused on the role of discourse of people involved to find out contextual factors that provoke the development of conflict over time.

\section{Conflict as Resistance to Change}

Conflict is often assumed to arise when there is incompatibility of ideas, beliefs, behaviours, roles, needs, desires, values, interests, etc. between individuals [3] [4] [5]. Resolving such incompatibilities leads, in some way, to change in attitude, perception, belief, norms, behaviour, roles, relationship, and so forth [5]. Change is a fundamental aspect of life as all societies even the most traditional ones evolve and change over time. However, people and communities react differently when confronted with change [4]. Any system cannot change without experiencing resistance as it is a naturally emerging part of the change process [5]. Resistance to change is the mobilization of opposing forces when people perceive they have divergent interest in the change process [5] [23]. Resistance to change initiative is thus an aspect of conflict [4] [5] [24]. Change and the way people and communities react to change are thus at the basis of all conflicts [4]. Engaging in planned or unplanned change gives rise to conflict and how these conflicts are resolved have a strong influence on the success of the change process [5]. Also, there is a strong similarity between the process of involving in successful change efforts and that of constructive conflict resolution [5]. So, understanding how and why resistance to change occurs will shed light on how and why conflicts emerge and evolve in participatory management of protected areas.

In management process, conflict originate in the different perceptions of the parties involved about who should manage, use and benefit from resources [4] [23]. The construction and representation of our perceptions and interpretations of the world around us are guided by the frames we construct in interaction [25] [26]. Frames are what we use to make sense of the world around us [26]. As Entman ([27] p. 52) put it "to frame is to select some aspects of a perceived real- 
ity and make them more salient in a communicating text, in such a way as to promote a particular problem definition, causal interpretation, moral evaluation, and/or treatment recommendation". Thus, frames play an important role in our perceptions and interpretations of a change process.

As the stakeholders involved in participatory natural resources management have different backgrounds, objectives, interests, and perspectives vis-à-vis the resources, they hold different frames about their management, use and benefit sharing [18] [19] [20] [21]. Participatory management is thus a change process aiming at triggering framing towards same or at least overlapping frames, which would enable the sustainable management of the resources. Such endeavour as any other change process may raise resistance from the stakeholders. Conflict is often associated with the differences in people's frames about the issue, what is important and how to respond to problems [28] [29]. Thus, studying frames will also inform about factors that contribute to the emergence and escalation of conflicts in natural resources management.

\section{Framing and Resistance to Change}

Early researches argued that three dimensions of attitude mainly determine resistance to change: cognitive, emotional, and intentional [30]. Ford et al. [24] reveal that, according to the literature of these researches, resistance occurs because change threaten the status quo, or increases fear and the anxiety of real and imagined consequences including threats to personal security and confidence in an ability to perform. Change may also encountered resistance because it threatens the way people make sense of the world, calling into question their values and rationality, and raising some form of self-justification [24]. Finally, resistance to change may develop because people distrust each other or have past experiences with those leading the change, when they have different understandings or assessments of the situation, or when they are protecting established social relations that they perceived to be threatened [18] [19] [20] [21] [24]. According to these views, people's resistance to a change process is linked to their socio-psychological state when the change is announced or introduced [24] [31] [32]. They resist to change because of the cognitive frames they hold when experiencing the change [32] [33]. Cognitive frames refer to the structures of expectations used by people to make sense of the world around them [18] [26] [29]. They are knowledge schemas, which refers to people's expectations about others, objects, events and settings in the world [29] [34]. So, resistance to change occurs when people feel a mismatch between their expectations and those the change may bring according to him [24]. When a change is introduced, people weigh the new information brought by the change with their past experiences and expectations before deciding whether or not to resist, comply or accept the change [24] [26]. Thus, resistance to change and therefore conflict emerges whenever a change is introduced which does not fit with the expectations of the people, no matter how it is introduced. From this perspective, deal- 
ing with such resistance to change consists in identifying the (potential) sources of mismatch between people's cognitive frames and the change's characteristics and choosing and implementing strategies appropriate for addressing and overcoming those sources [3] [24]. The job of the change agent is thus to align, fit, or adapt the change process through interventions, to the cognitive frames of the stakeholders [3] [17].

However, change also happens without major conflict although incompatibilities with people's expectations and experiences about the change were presumed to exist at start [35]. In contrary, changes that were thought to be compatible with the expectations and experiences of people may raise conflict when introduced [36]. Likewise, resistances also emerge later after changes were introduced or agreements were reached without any resistance at the beginning of the process [9]. These different conflict emergence situations show that change is not just a reality that fit or not to the expectations and the experiences of people and raises resistance whenever it does not [17]. Rather, change is a socially constructed reality in which, the reality we know as change is continuously interpreted, constructed, enacted, and maintained or rejected through discourse [17]. Resistance to change is therefore not to be found only in the individuals' cognitive frames at the beginning of the change process or the background characteristics of the social context in which the change is introduced, but mainly in the constructed reality in which people operate [24]. Reality construction in interaction refers to interactional framing, which represents the co-construction of agreed-upon ways to make sense of a situation [18] [26] [29] [34]. Interactional frames produced are alignments co-constructed through social actors' discourses in interactions [18] [25] [26] [29]. So, resistance to change occurs when individuals fail to co-construct same or at least overlapping frames in interaction when a change is introduced or announced. Conflict is thus a sequence of interactions, and it is the frames constructed during this sequence rather than background conditions that determines the conflict [37].

In summary, a process of change starts in a context where people involved in the process hold cognitive frames about the change introduced, which may be incompatible. We posit that this does not automatically mean the emergence of conflict as the reality known as change that may raise resistance is co-constructed through people's discourses in interaction [17] [18] [19] [24] [35]. Resistance to the change or conflict may then emerge only when people involved in the change process fail to co-construct or negotiate alignments about the change in interaction [18] [19] [20] [21].

The frames co-constructed in a change process may be the result of the reframing of people's cognitive frames held at the beginning of the process or their reinforcement in light of the new information encountered and new relationships built in interaction. Once these cognitive frames are built, the conflict no longer revolves around the issue of change but rather centers on them-the cognitive frames-defining the behaviours, relationships and institutions that form 
the context of the conflict [2]. Successful intervention in such situations requires change in the social system [2] [38]. Discourse plays a significant role in such interaction process [18] [38] [39].

\section{Discourse, Context and Resistance to Change}

Discourse is often associated with discussion, debate or exchange of views with regard to a certain social or political topic in daily language [40]. In that sense, it is considered as a simple medium for communication. Discourse is also considered as a social practice as put in evidence by the work of Michel Foucault and others [40]. In policy process for example, according to Schmidt "discourse... consists of whatever policy actors say to one another and the public in their efforts to generate and legitimize a policy program. As such, discourse encompasses both a set of policy ideas and values and an interactive process of policy construction and communication" ([41] p. 210).

However, although post-modernists and constructivists would argue that reality is discursively constructed, it does not imply that analysis of social practices should be limited to discourse [12]. Discourse cannot be analyzed in isolation and needs to be understood in institutional context [12]. Institutions are sets of formal and informal rules that enable and structure all forms of social interaction [19] [40] [42] [43]. They are norms and arrangements that set the parameters of what people talk about as well as of who talks to whom in the process of change [12]. Thus, institutions structure and constrain discourse. They shape discursive activity in a change process [15].

There is also a strong relationship between discourse and power, but not just in the sense that people exert power by means of discourse rather, power is in the discourse [40] [44] [45]. This means that discourse should be considered not only as other factors that influence the change process, but also in terms of the rules that constrain and enable some discourses related to the change in institutional settings [12]. As such, discourse embodies the institutional context and is made of rules and procedures that construct and legitimate the way we see things and talk about them [19] [46]. Discourse disciplines human agencies to think, speak and act in a certain way and not in others [19] [40]. In that sense, discourse not only restricts, limits and arranges what can and cannot be said about a phenomena within its domain; it also empowers (and disempowers) certain agents to speak on this or that question or fact [46]. Thus, discourse creates the context that favours and triggers or not change and resistance to change. The framing of a change process in certain discursive form then mobilizes support and/or resistance discourses from those for whom the change is initiated and also reproduces and transforms power relations [46]. Therefore, strategic framing of change discourse becomes a key to the successful control of people's interpretation of the change process as discourses create ways of understanding the world (frames) and do not just mirror reality [27] [46] [47].

In brief, the emergence of conflict is linked to the management of a change 
process to overcome the incompatibilities between people, groups or organizations. The existence of incompatibilities between individuals does not automatically mean a conflict unless these incompatibilities are evoked in discourse in interaction [35]. Conflict emerges from discourses that represent the mental and behavioural patterns (frames) defining the relationships and institutions that form the context of the conflict [2]. We also looked at contextual factors and patterns that may explain the evolution of conflicts towards escalation.

\section{Escalation of Resistance to Change}

Escalation is a significant change in the nature of the conflict towards an increase of violence as different from the gradual intensification of conflict with no definable change in its nature [48] [49].

Escalation of conflict is attributed by some scholars to the cognitive frames of the parties. For example, De Dreu [33] identified two cognitive tendencies that contribute to the escalation of conflict. According to him, conflict escalates because of the ego defensiveness of parties in conflict. People tend to develop and maintain positive self-view, which means they see themselves as benevolent and constructive and their counterparts as malevolent and competitive [33]. They then tend to react aggressively and become more hostile when their positive self-view is threatened [33]. Conflicts also escalate because of naïve realism of the parties [33]. Naïve realism suggest that individuals believe the world is as they perceive it and that other people view the world in that same way otherwise this is due to their lack of information, lack of intelligence, or ulterior motive. They see the action and the reactions of the other party and react to that as if they have the same reasons for conflict. Naivve realism is based on the assumption that the total value in a conflict is fixed and that negotiation is about distributing that value rather than creating additional value [33]. Both ego defensiveness and naïve realism are related to people's cognitive frames.

Others scholars see escalation as the product of the interactive choices of the parties and that interaction should be used as unit of analysis of conflict escalation [50]. Escalation then consists of a set of interactions involving an action taken by one party that may be perceived as provocation by the other party and the latter retaliates to it, which may be in turn seen as provocation by the former, and so on [48] [50]. Escalated conflicts are thus hard to undo because the retaliations create a vicious cycle [23]. Resistance to change or conflict escalates when tactics or means used to trigger change were perceived as aggressive or contentious [23]. Conflict escalates also when there are changes in the view of each other during the conflict, or when weakened interpersonal bonds among the parties exists [23]. Conflict escalation thus occurs when there is a shift of parties' frames about each other, their actions and relationships towards more aggressive and contentious frames in social interactions during the conflict [29].

We posit that like conflict emergence, conflict escalates when the cognitive frames built by the parties when the conflict is established shift towards more 
aggressive and contentious frames in response to the behaviour, action or discourse of the parties in interaction. We thus looked for contextual clues and mechanisms that play a major role in the development of conflict towards escalation.

In light of the above discussion, we built the analytical framework of Figure 1 to understand conflict emergence and escalation in a change process.

The analytical framework below shows that a change process is always introduced in a context where people already hold cognitive frames and discourses related to the change built from their past experiences and expectations. The change introduced thus triggered the creation of a new reality through discourses characterised by the change (its characteristics), institutions, relationships, and actions that emerge in the framework of the change process. Parties co-construct discourses and frames related to these characteristics of the context in which the change process is unfolding. The result of such process may be the building of overlapping or same frames and discourses about the new reality constructed by the parties and thus enabling the smooth and collaborative implementation of the change. The process may also result in the construction of opposing discourses and frames about the change and thus raise overt or hidden

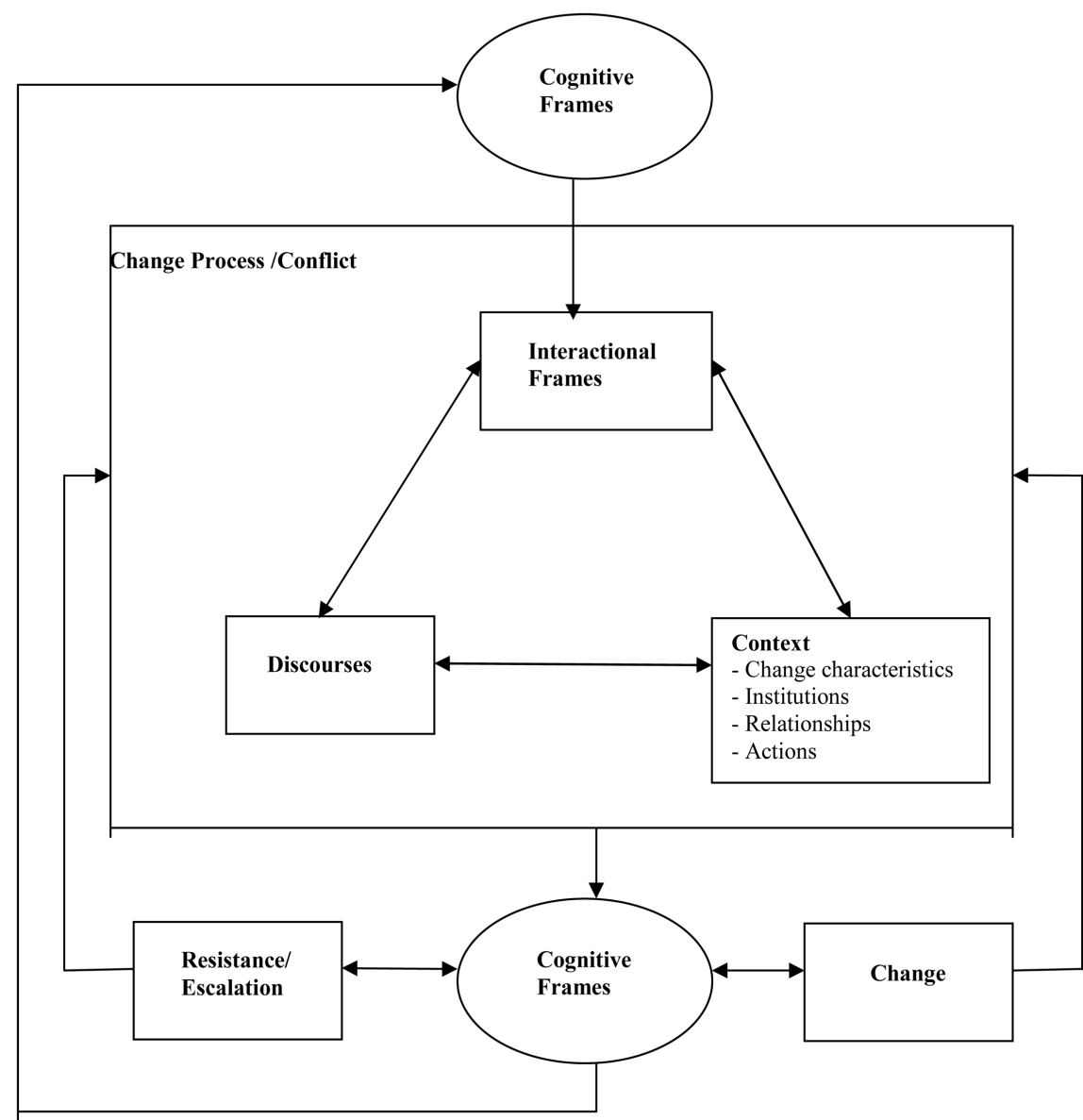

Figure 1. Framework for understanding conflict emergence and escalation in a change process. 
resistance to the change or conflict [20]. In both cases, the process of co-construction of discourses and frames in interaction about the context continue over time and resistance may emerge later after a successful start or the conflict may escalate in the resistance case if new events trigger more aggressive and contentious discourses and frames construction. We used this framework to analyse three cases of conflict in the implementation of participatory management of natural resources in Benin.

\section{The Cases Studies}

Several protected areas were created in Benin by the colonial administration between 1940 and 1960 to protect these ecosystems from complete depletion. The fact that these protected areas where established without the consent of the local communities whose lands were even confiscated, their management was characterised with conflicts between the forest department and the local communities. The forest department struggled to keep the local communities away from them by force and repression and the local communities took any occasion to use these resources on which their livelihood depends. Participatory management of Benin's protected areas was then enacted in 1993 after the protectionism mechanism failed and local communities were invited to collaborate in the management of the protected areas with the forest department. However, after few years of lull, in several cases conflicts re-emerged between the forest department representatives and local communities and even escalated in the attempts to their resolution. Three cases were analysed in the framework of this study to unravel contextual factors and clues that contribute to the emergence and escalation of conflicts in the participatory management of the natural resources in Benin (see [18] [19] [20]).

\subsection{Conflict in the Participatory Restoration of Agoua Forest}

Agoua forest in Benin was put under State protection in 1953 and subsequently managed by means of coercion system. However, the local communities managed to settle in the forest when looking for land for agriculture and created plantations and several villages. In 2002, a participatory management project was launched to restore this forest. The local communities welcomed the project as it was introduced to them to help improve their livelihood. So, instead of chasing all the farmers outside the forest, the project decided to design a plan for the resettlement of the farmers. The plan divided the forest in four zones: the service zones for roads to access the villages in the forest, the agro-forestry zones where all the farmers scattered in the forest should settle, and the protection and production zones where no farmer is allowed to settle and dedicated to be enriched to restore the forest with forest trees. The managers of the project and local communities' representatives agreed on the plan at the beginning of the project. However, when the implementation phase of the plan was announced by the project, the local communities opposed to it. They started blaming the 
project, which they considered as untrustworthy because it has changed the initial objectives and agreements. Their frames about the project shifted from positive to negative and the emergence of a conflict was perceptible in their discourse when the implementation of the zoning plan was announced [18].

When the project ordered the destruction of a cashew plantation in the forest, which should be replaced with a forest tree plantation, the local communities decided to undertake some actions against the project without communicating them to its managers. They wrote a letter to Benin's President with copies to the ministries of environment and agriculture to complained about the project, which they said was hindering their efforts to increase production of mandate crops in their region by destroying their farms. They also organized a march against the project and invited the national television to broadcast it for the sake of being heard by the nationwide public and gain its support.

Two negotiation meetings to solve the conflict were organised among the project team members, the local communities' representatives, the municipality staff, and the representatives of the ministries of agriculture and environment. The negotiation meetings held did not solve the conflict, which even escalated. Although a new agreement between the parties was signed to solve the conflict at the last negotiation meeting, the project ended in an impasse characterized by distrust, accusations and even threats among the parties only noticeable in their discourses when discussing separately with them [18]. For the project managers, who believed that the conflict was over because the agreement was signed by the local communities' representatives at the negotiation meetings, the local communities will leave the production and protection zones after 8 years of memorandum given to them without any condition. Whereas for the local communities, even though they have signed the agreement, they did not agree with the project's propositions and did not express it at the meetings because they were in minority. They thus postponed their fight even to death against anybody who will try to chase them from "their lands" after the end of the memorandum. Thus, the discourses of the different parties in we-groups of identical stakeholders show that their main frames were not discussed at the meetings and that the conflict even became more contentious after the negotiation [18].

\subsection{Conflict in the Implementation of the Participatory Management Plan (PMP) of OSN Forests}

The Ouémé Supérieur (OS) and N'dali (N) forests were declared protected areas by the State respectively in 1952 and 1942. After more than four decades of their management with coercion system by the forest department, participation was introduced in 1993 through the project of natural resources management (PGRN: Projet de Gestion des Ressources Naturelles). The participatory management of OSN forests consisted in the preparation and implementation of their participatory management plan (PMP). The PMP was establishment through many meetings with all the stakeholders including local communities, the PGRN staff 
members, the forest department representatives and the facilitators of the Cooperative League of the United States of America (CLUSA), an American NGO supporting the project through training and facilitation activities. These different meetings enabled the development of social cohesion among the stakeholders, which facilitated later the implementation of the PMP after the end of the project [19]. The social cohesion between the forest rangers and the local communities was built when organising together some activities such as logging, reforestation and surveillance of the forests and sharing the benefits. In fact, the implementation of the PMP started with the same stakeholders who participated to its establishment. Thus, the social cohesion developed among them during the establishment phase enabled them to build informal rules, roles, and relationships that facilitated the continuation of the activities undertaken during the PGRN phase. These informal rules and roles were the stakeholders' interpretation of the formal institutions set up by the PMP for the management of the forests that enabled the smooth evolution of the participatory process.

However, a few years after the beginning of the implementation phase of the PMP, the forest department replaced the forest rangers who participated to the establishment of the PMP in the villages surrounding the OSN forest thus in the PMP implementation. A conflict of roles, rules and responsibilities sharing between the forest rangers and the local communities in the implementation of the PMP arose when the new forest rangers arrived. Whereas the local communities were still committed to the informal roles, rules and responsibilities built with the former forest rangers, the new forest rangers wanted to follow the formal institutions as stated by the PMP. They considered that the local communities were going beyond their roles with the informal rules and responsibilities sharing. At the same time for the local communities, the new forest rangers did not want to consider them as partners but as their workmen.

The conflict escalated when a new project, the programme of forests and adjacent lands management (PGFTR: Projet de Gestion des Forêts et Terroirs Riverains), launched to support the implementation of the PMP did not organise meetings to discuss and rebuild social cohesion among the stakeholders and rather stopped the main activity carried out together by the forest rangers and the local communities, which was organising logging. For the local communities, the forest department suspended logging to dispossess them from the power they have been granted in the participatory management process and to carry it alone. They noticed that since the suspension, logging has developed anarchically in the OSN forests and they accused the forest rangers to organise it. In the contrary, according to the forest department, logging was suspended because it was not being carried out as described in the PMP. The appointment of new forest rangers broke the "we" group created by the local communities and the former forest rangers that enabled the development of a new communication group. However, there was no room for the new forest rangers and the local communities to discuss together their different frames, which created more dis- 
tance and stigmatization among them.

\subsection{Conflict in the Participatory Management of the Pendjari National Park (PNP)}

The Pendjari national park (PNP) was created in 1954 and managed solely by the forest department until participation was introduced in 1993. However, the participatory management of the PNP effectively started in 2000 when the park management directorate decided to scale up the approach to the whole park after it was tested in one of the villages bordering the park. The management of the park until participation was introduced was characterised by many conflicts between the forest rangers and the local communities on the resources use. Some local communities, who were living in the park were chased away provoking clashes, which ended with many deaths of villagers and their animals shot by the forest rangers. The local communities were also forbidden to enter the park for any reason. Thus, when participation was introduced, the local communities were reluctant to participate. The park management directorate undertook several actions to build trustful relationship with the local communities and gain their collaboration [20]. The park management directorate replaced progressively the forest rangers by eco-guards, who are young men recruited in the villages surrounding the park to carry out surveillances in the park. The park management directorate also releases each year, $30 \%$ of the benefits deriving from game hunting organized for the tourists in the park to local communities and gives systematically the animal killed to them. The local communities are involved in the organisation of these activities and in the surveillance of the park. They are also allowed to access the park to carry out their rituals and sacrifices for their gods still in the park, to harvest non-timber resources, and to bring their cattle to the rivers in the park for watering. Finally, the park management directorate delimitated a zone of 5 kilometres wide around the park where the local communities are allowed to crop. These actions enabled the development of trust between the park management directorate and the local communities, which improved the surveillance and management of the park with the collaboration of local communities and consequently the raise of wild animals in the park [20].

However, almost five years after the beginning of the participatory process, the park management directorate noticed the decreased of wildlife as a result of the raise of poaching in the park. A conflict thus emerged between the park management directorate and the eco-guards, who started accusing each other for being responsible of the situation. The park management directorate explained the raise of poaching in the park by accusing the eco-guards for becoming complacent and less motivated than they were at the beginning of the process. According to the park management directorate, this is due to the fact that it has secured the eco-guards' job by declaring them permanent agents of the park management directorate what made them overconfident about their job situation and harmed their motivation. For the eco-guards who agreed with the fact 
that they became less motivated compared to the beginning of the process, their behaviour was due to their distrust to the park management directorate. According to them, they lost hope for the achievement of their expectations and promises about their career by the park management directorate on which their relationship was built upon. As a result, they became de-motivated. However, the conflict was hidden as these accusations and blames where only noticeable when discussing separately with the stakeholders. The conflict was hidden by the illusion of peaceful relationships between the stakeholders in formal settings such as meetings and interactions involving both parties.

The conflict escalated as to correct the situation, the park direction decided to negotiate and involve the poachers in the surveillance of the park instead of discussing the issue with the eco-guards and finding an agree upon solution. The park management directorate supported its decision with its distrust to the eco-guards and thus took actions to protect itself. The eco-guards in the other hand disagree with the decision and showed that they did not trust the poachers they considered as opportunistic reconverted. They also considered this decision of the park direction as a confirmation of its willingness to not fulfill its engagements vis-à-vis the eco-guards.

\section{Discussion and Conclusions}

The three case studies presented in this study put in evidence three situations where conflict emerged and escalated in the participatory management of natural resources. These cases showed how stakeholders managed to build collaboration at start but failed to sustain it and gave raise to conflict. They gave us more insights in understanding conflicts' emergence and escalation in participatory processes as discussed below.

\subsection{Conflict Emergence in Participatory Natural Resources Management}

Conflict or resistance to change is often defined as the situation where there are divergences or incompatibilities among individuals involved in a process [3] [4] [5] [23]. Our case studies show that incompatibilities among individuals raise conflict when they are evoked in interaction through discourses [18] [24] [48]. In fact, stakeholders co-construct and negotiate frames through discourses in interactions [25] [26]. Conflict is thus a situation where stakeholders co-construct opposing instead of same or at least overlapping frames through discourses in interaction when a change is introduced or announced [25] [26].

In the three case studies, participatory process started with a lot of enthusiasm and no manifested resistance although the stakeholders had different interests, background, objectives, and perspectives vis-à-vis the resources. The projects in all the cases held positive discourses to introduce the change in the management of natural resources to the local communities. The local communities reciprocated to the discourses of the representatives of the forest department by constructing positive frames about the change expressed in their discourses as well. 
Thus, overlapping frames about the process were co-constructed by the project managers and the local communities, which enabled them to collaborate and implement the process for a relatively important period of time in the different cases. Resistance emerged later due to the change in discourses of the projects or the managers, which triggered the construction of opposing frames. Resistance to change is thus the product of the parties' interactive discursive choices [48]. The outcome of a change process is thus determined by the interdependence between the people involved and the way in which the process is built. It cannot be understood or explained by the behaviour of an involved individual or an interaction but by chains of interactions that happened during the course of the process in which discourses play a determinant role [17] [24]. The conflict in the Agoua case emerged when the project changed its discourse and announced the start of the implementation of the zoning plan. This discourse triggered frame shift to the local communities' side and they started considering the project as negative. The local communities reacted to the discourse of the project by expressing negative discourses, which reflected their new frames. In the case of the OSN forests, the conflict also emerged when the new forest rangers appointed held discourse about the institutional setting, which rejected the informal institutions co-constructed by the former forest rangers and the local communities. The local communities in this case also made sense of this change in the discourse held by the new forest rangers by constructing negative frames to characterize them, expressed it in their discourses and thus opposed to the change in roles and responsibilities. The conflict arose in the case of the PNP from the shift of the eco-guards' frames about the park management directorate in reaction to their feeling that the park management directorate was not respecting its promises concerning their career. The opposition of frames raised in this case from the lack of overt and clear communication between the park management directorate and the eco-guards about the needs and expectations of the eco-guards, what made this conflict a hidden one. The park management directorate considered the eco-guards as exaggerating their needs whereas the eco-guards viewed the park management directorate as untrustworthy because it was not fulfilling its promises of the beginning towards them. So in all these cases, conflict arose in correlation with the shift of discourses held in the different interactional contexts, which led to the shift in frames from positive to negative. The opposing discourses of both parties were constructed and held only in we-groups without bringing them to the fore to be discussed at meetings involving both parties.

Change and reaction to change are thus a process of discursive co-construction of realities [17] [24] [48]. The way change is presented in discourses determines the frames constructed and set at the same time the path for new discourses that emerge as reaction. Discourses are thus path-dependent as they are built from former discourses and at the same time set the path for upcoming discourses [36] [40]. The change in discourse should be considered as at the core of the process of change as it provides with new frames, which can be appro- 
priated, edited and partially appropriated, or resisted [15] [24]. Discourse is thus central in change process in giving shape to the institutional structure of the process, as a set of ideas about the new rules, values and practices, and at the same time as a resource used to produce and legitimate those ideas, as a process of interaction focused on formulating and communicating the change [12]. In all the three cases, the conflicts escalated.

\subsection{Conflict Escalation in Participatory Natural Resources Management}

Once a conflict is established, the opposed frames co-constructed in interaction evolve towards cognitive frames, which become stable [2]. Unless these frames change, the conflict endures [15] [40]. This is where negotiation process plays a significant role. However, most negotiation processes target agreements, pay less attention to the frames of the stakeholders and sometimes lead the conflict to escalation. In the Agoua case, at the two negotiation meetings held, the project managers strove to make the local communities accept the zoning plan by making propositions that they had signed. The frames constructed in we-groups were not discussed at the meetings. Nothing was done in both sides to bring to the fore the frames constructed by each group of stakeholder behind the negotiation scene, which were opposed. The negotiation process rather turned out to be an intimidation of the farmers to sign their proposition. Thus, the negotiation process rather escalated the conflict noticeable in the frames of the stakeholders after the process, which became more aggressive and expressed blaming, accusations and threats to the project managers. In the case of the OSN forests conflict, the new project which was supposed to conduct the negotiation between the local communities and the forest guards stopped logging activities, which were the main activities both parties were carrying together. The better organization of this activity could had enabled the rebuilding and strengthening of social cohesion between the parties through the interaction it would have enacted but it was stop and the conflict escalated. The stop of this activity triggered more contentious frames at the local communities' side and they assimilated this decision to a strategy of the forest department to withdraw the power sharing mechanism, the participatory process. As for the conflict, which opposed the eco-guards to the park management directorate, it escalated when the park management directorate decided to involved the poachers in the surveillance without making this decision with the eco-guards. The eco-guards framed this decision as malevolent and it triggered more distrust to the park direction in its willingness to respect its engagement vis-à-vis the eco-guards.

The above analysis shows that the conflicts escalated during the negotiations in relation to the lack of mechanisms that should constrain and or enable the different stakeholders to bring to the fore their different frames constructed in we-groups to be discussed. Either these mechanisms were lacking or they failed to create the conditions that would stimulate the discussion of main frames of 
the parties at the meetings. Thus, the opposing cognitive frames of the stakeholders became more contentious in terms of distrust and widened the distance created by the conflict between them.

We learn from this study that conflicts emerge and escalate when the strategic framing of the stakeholders in interaction leads to opposing frames. We should accept that we cannot control people's strategic framing. We can only be alert to discover changes and clues in discourse that contribute to the divergence of frames. Negotiation in change process or wishing to end conflict should thus target the creation of conditions for the parties' strategic framing towards same or at least overlapping frames by stimulating more interactions where the opposing frames could be discussed [12] [15] [17] [24] [40] [47]. Conflict emerged and escalated in the three cases due to the decrease of interaction over time between the stakeholders, which did not enable them to enhance social cohesion and trust important to discuss the main issues that opposed them. Both formal and informal interaction arenas should be continuously checked in change process with or without resistance as opposing frames are susceptible to emerge and are not often brought to the fore in official negotiations [18] [19] [20] [21].

\section{References}

[1] Deutsch, M. (2006) Introduction. In: Deutsch, M., Coleman, P.T. and Marcus, E.C., Eds., The Handbook of Conflict Resolution: Theory \& Practice, Jossey-Bass, San Francisco.

[2] Coleman, P.T., Vallacher, R.R., Nowak, A. and Bui-Wrzosinska, L. (2007) Intractable Conflict as an Attractor: A Dynamical Systems Approach to Conflict Escalation and Intractability. Journal of Black Studies, 37, 1454-1475.

[3] Adams, W.M., Brockington, D., Dyson, J. and Vira, B. (2003) Managing Tragedies: Understanding Conflict over Common Pool Resources. Science, 302, 1915-1916. https://doi.org/10.1126/science.1087771

[4] Desloges, C. and Gauthier, M. (1997) Community Forestry and Forest Resource Conflicts-An Overview. XI World Forestry Congress, Antalya, FAO Forestry Department, Turkey.

[5] Marcus, E.C. (2006) Change and Conflict: Motivation, Resistance, and Commitment. In Deutsch, M., Coleman, P.T. and Marcus, E.C., Eds., The Handbook of Conflict Resolution: Theory \& Practice, Jossey-Bass, San Francisco.

[6] Smith, D. (1997) Language and Discourse in Conflict and Conflict Resolution. Current Issues in Language and Society, 4, 190-214. https://doi.org/10.1080/13520529709615498

[7] Buckles, D. (1999) Cultivating Peace: Conflict and Collaboration in Natural Resource Management. IDRC/World Bank.

[8] Tyler, S.R. (1999) Policy Implication of Natural Resource Conflict Management. In: Buckles, D., Ed., Cultivating Peace: Conflict and Collaboration in Natural Resource Management, World Bank Institute, Washington DC.

[9] Castro, A.P. and Nielson, E. (2003) Indigenous People and Co-Management: Implications for Conflict Management. Environmental Science \& Policy, 4, 229-239. https://doi.org/10.1016/S1462-9011(01)00022-3

[10] Hares, M. (2009) Forest Conflict in Thailand: Northern Minorities in Focus. Envi- 
ronmental Management, 43, 381-395. https://doi.org/10.1007/s00267-008-9239-7

[11] Hellström, E. (2001) Conflict Cultures-Qualitative Comparative Analysis of Environmental Conflicts in Forestry. In: Silva Fennica Monographs.

[12] Schmidt, V.A. and Radaelli, C.M. (2004) Policy Change and Discourse in Europe: Conceptual and Methodological Issues. West European Politics, 27, 183-210. https://doi.org/10.1080/0140238042000214874

[13] Brown, A.D., Gabriel, Y. and Gherardi, S. (2009) Storytelling and Change: An Unfolding Story. Organization, 16, 323-333.

https://doi.org/10.1177/1350508409102298

[14] Teram, E. (2010) Organizational Change within Morally Ambiguous Contexts: A Case Study of Conflicting Postmerger Discourses. Journal of Applied Behavioral Science, 46, 38-54. https://doi.org/10.1177/0021886309357539

[15] Chreim, S. (2006) Managerial Frames and Institutional Discourses of Change: Employee Appropriation and Resistance. Organization Studies, 27, 1261-1287. https://doi.org/10.1177/0170840606064106

[16] Weick, K.E. (1995) Sense-Making in Organizations. Sage, Thousand Oaks.

[17] Ford, J.D. (1999) Organizational Change as Shifting Conversations. Journal of Organizational Change Management, 12, 480-500. https://doi.org/10.1108/09534819910300855

[18] Idrissou, L., Aarts, N., Paassen, A.V. and Leeuwis, C. (2011) The Discursive Construction of Conflict in Participatory Forest Management: The Case of Agoua Forest Restoration in Benin. Conservation and Society, 9, 119-131. https://doi.org/10.4103/0972-4923.83722

[19] Idrissou, L., Aarts, N., Paassen, A.V. and Leeuwis, C. (2011) From Cohesion to Conflict in Participatory Forests Management: The Case of Ouémé Supérieur and N'Dali (OSN) Forests Management. Forest Policy and Economics, 13, 525-534.

[20] Idrissou, L., Aarts, N., van Paassen, A., Vodouhè, S. and Leeuwis, C. (2013) Trust and Hidden Conflict in Participatory Natural Resources Management: The Case of the Pendjari National Park (PNP) in Benin. Forest Policy and Economics, 27, 525 534.

[21] Idrissou, L., Aarts, N., Paassen, A.V. and Leeuwis, C. (2011) Identity Dynamics and Conflict in Collaborative Processes: The Case of Participatory Management of Protected Areas in Benin. Journal of Environmental Protection, 7, 1981-2008. https://doi.org/10.4236/jep.2016.713154

[22] Marfo, E. (2006) Powerful Relations: The Role of Actor-Empowerment in the Management of Natural Resource Conflict. A Case of Forest Conflicts in Ghana.

[23] Friedman, R.A. and Currall, S.C. (2003) Conflict Escalation: Dispute Exacerbating Elements of E-Mail Communication. Human Relations, 56, 1325-1347. https://doi.org/10.1177/00187267035611003

[24] Ford, J.D., Ford, L.W. and McNamara, R.T. (2002) Resistance and the Background Conversations of Change. Journal of Organizational Change Management, 15, 105 121. https://doi.org/10.1108/09534810210422991

[25] Aarts, N. and van Woerkum, C. (2006) Frame Construction in Interaction. 12th MOPAN International Conference, Pontypridd.

[26] Gray, B. (2003) Framing of Environmental Disputes. In: Lewicki, R.J., Gray, B. and Elliot, M., Eds., Making Sense of Intractable-Environmental Conflicts. Concepts and Cases, Irland Press.

[27] Entman, R. (1993) Framing toward Clarification of a Fractured Paradigm. Journal 
of Communication, 43, 51-58. https://doi.org/10.1111/j.1460-2466.1993.tb01304.x

[28] De Dreu, C.K.W. and McCusker, C. (1997) Gain-Loss Frames and Cooperation in Two-Person Social Dilemmas: A Transformational Analysis. Journal of Personality and Social Psychology, 72, 1093-1106. https://doi.org/10.1037/0022-3514.72.5.1093

[29] Dewulf, A., Gray, B., Putnam, L., Lewicki, R., Aarts, N., Bouwen, R. and Van Woerkum, C. (2009) Disentangling Approaches to Framing in Conflict and Negotiation Research: A Meta-Paradigmatic Perspective. Human Relations, 62, 155-193. https://doi.org/10.1177/0018726708100356

[30] Piderit, S.K. (2000) Rethinking Resistance and Recognizing Ambivalence: A Multidimensional View of Attitudes toward an Organizational Change. Academy of Management Review, 25, 783-794.

[31] Dent, E.B. and Susan Galloway Goldberg (1999) Challenging Resistance to Change. The Journal of Applied Behavioral Science, 35, 25-41. https://doi.org/10.1177/0021886399351003

[32] Winter, D.G. (2004) Motivation and the Escalation of Conflict: Case Studies of Individual Leaders. Peace and Conflict, 10, 381-398. https://doi.org/10.1207/s15327949pac1004_8

[33] De Dreu, C.K.W. (2005) A PACT against Conflict Escalation in Negotiation and Dispute Resolution. Current Directions in Psychological Science, 14, 149-152. https://doi.org/10.1111/j.0963-7214.2005.00349.x

[34] Tannen, D. and Wallat, C. (1987) Interaction Frames and Knowledge Schemas in Interaction: Examples from a Medical Examination/Interview. Social Psychology Quarterly, 50, 205-217. https://doi.org/10.2307/2786752

[35] Winstok, Z. (2008) Conflict Escalation to Violence and Escalation of Violent Conflicts. Children and Youth Services Review, 30, 297-310.

[36] Ha, Y., Joo, J., Kang, M., Lah, T.J. and Jang, J. (2009) Social Conflicts and PolicyMaking in Korea: Interpretation of Policy Failures through a Public Discourse Perspective. International Review of Administrative Sciences, 75, 649-664. https://doi.org/10.1177/0020852309351447

[37] Moritz, M. (2010) Understanding Herder-Farmer Conflicts in West Africa: Outline of a Processual Approach. Human Organization, 69, 138-148. https://doi.org/10.17730/humo.69.2.aq85k02453w83363

[38] Leeuwis, C. and Aarts, N. (2011) Rethinking Communication in Innovation Process: Creating Space for Change in Complex Systems. Journal of Agricultural Education and Extension, 17, 21-36. https://doi.org/10.1080/1389224X.2011.536344

[39] Kykyri, V.L., Puutio, R. and Wahlstrom, J. (2010) Inviting Participation in Organizational Change through Ownership Talk. Journal of Applied Behavioral Science, 46, 92-118. https://doi.org/10.1177/0021886309357441

[40] Arts, B. and Buizer, M. (2009) Forests, Discourses, Institutions. A Discursive-Institutional Analysis of Global Forest Governance. Forest Policy and Economics, 11, 340-347.

[41] Schmidt, V.A. (2002) Does Discourse Matter in the Politics of Welfare State Adjustment? Comparative Political Studies, 35, 168-193. https://doi.org/10.1177/0010414002035002002

[42] Torniainen, T.J. and Saastamoinen, O.J. (2007) Formal and Informal Institutions and Their Hierarchy in the Regulation of the Forest Lease in Russia. Forestry, 80, 489-501. https://doi.org/10.1093/forestry/cpm033

[43] Woodhill, J. (2008) How Institutions Evolve-Shaping Behaviour. The Broker 
Online, No. 10, 4-8.

[44] Foucault, M. (1994) Power. The New Press, New York.

[45] Hook, D. (2001) Discourse, Knowledge, Materiality, History: Foucault and Discourse Analysis. Theory and Psychology, 11, 521-547. https://doi.org/10.1177/0959354301114006

[46] De Cock, C. (1998) Organisational Change and Discourse: Hegemony, Resistance and Reconstitution. Management, 1, 1-22.

[47] Masozera, M.K., Alavalapati, J.R.R., Jacobson, S.K. and Shrestha, R.K. (2006) Assessing the Suitability of Community-Based Management for the Nyungwe Forest Reserve, Rwanda. Forest Policy and Economics, 8, 206-216.

[48] Sislin, J. and Pearson, F. (2006) Arms and Escalation in Ethnic Conflicts: The Case of Sri Lanka. International Studies Perspectives, 7, 137-158. https://doi.org/10.1111/j.1528-3585.2006.00236.x

[49] Zartman, I. and William, E.D. (1995) Elusive Peace: Negotiating an End to Civil Wars. Brookings Institution, Washington DC.

[50] Winstok, Z., Eisikovits, Z. and Fishman, G. (2004) Towards the Development of a Conflict Escalation Model: The Case of Israeli Youth. Journal of Youth and Adolescence, 33, 283-292. https://doi.org/10.1023/B:JOYO.0000032637.13780.14

Submit or recommend next manuscript to SCIRP and we will provide best service for you:

Accepting pre-submission inquiries through Email, Facebook, LinkedIn, Twitter, etc. A wide selection of journals (inclusive of 9 subjects, more than 200 journals) Providing 24-hour high-quality service User-friendly online submission system Fair and swift peer-review system Efficient typesetting and proofreading procedure Display of the result of downloads and visits, as well as the number of cited articles Maximum dissemination of your research work

Submit your manuscript at: http://papersubmission.scirp.org/

Or contact gep@scirp.org 